\title{
Carcinogenicity Studies in Rodents with Ripazepam, a Minor Tranquilizing Agent
}

\author{
J. E. Fitzgerald, F. A. DE LA Iglesia, AND E. J. MCGuire \\ Department of Pathology and Experimental Toxicology, Warner-Lambert/Parke-Davis Pharmaceutical Research, \\ Warner-Lambert Company, Ann Arbor, Michigan 48105, and Department of Environmental and Industrial \\ Health, University of Michigan, Ann Arbor, Michigan 48109
}

\begin{abstract}
Carcinogenicity Studies in Rodents with Ripazepam, a Minor Tranquilizing Agent. FITZGERALD, J. E., DE LA IGLESIA, F. A., AND MCGuire, E. J. (1984). Fundam. Appl. Pharmacol. 4, 178190. The carcinogenesis potential of ripazepam, a benzodiazepine derivative, was studied in mice and rats for 78 and 104 weeks, respectively. Groups of 50 male and 50 female CD1 mice and $\mathrm{CD}$ rats each were given doses of 15 and $150 \mathrm{mg} / \mathrm{kg}$ of ripazepam in the diet. Survival rates were adequate for statistical analysis. Significant suppression of body weight gains occurred in rats but not in mice given $150 \mathrm{mg} / \mathrm{kg} /$ day. The compound failed to increase tumor rates or alter the average latency of neoplasms in the rat. In mice, the number of male animals with tumors was increased at $150 \mathrm{mg} / \mathrm{kg}$ and this was related to a significant increase in the number of animals with hepatocellular tumors. Hepatocellular tumors were increased also in female mice but the increase was not statistically significant. All but one of these hepatic neoplasms were hepatocellular adenomas and the one carcinoma had not metastasized. Other tumor types were not increased.
\end{abstract}

Ripazepam, also recognized as CI-683 or Pyrazapon, is a pyrazolodiazepinone which has demonstrated anxiolytic effects in animal pharmacologic tests. It is identified chemically as 1-ethyl-4,6-dihydro-3-methyl-8-phenylpyrazolo[ $[4,3, \mathrm{e}][1,4]$ diazopine and is structurally related to other diazopinone (Fig. 1) derivatives such as diazepam, oxazepam, and prazepam.

The pharmacologic profile of the compound was determined previously in mice, rats, monkeys, and rabbits (Poschel et al., 1974). In animal tests, ripazepam had the desired properties of a potent antianxiety effect without strong sedative or depressant activity.

The toxicity of diazepines has been reviewed (Randall et al., 1974) and effects on reproduction and development have been investigated (Fox, 1975; Guerriero and Fox, 1976); however, only a few carcinogenesis bioassays with this class of compound are available. In a limited study, hepatic cell adenomas and peliosis hepatis were reported in mice following the feeding of oxazepam for several months (Fox and Lahcen, 1974). More recently, pra- zepam at multiple dose levels and diazepam at one dose level were not carcinogenetic (de la Iglesia et al., 1981).

\section{METHODS}

Chemical. Pharmaceutical grade ripazepam was supplied as a pale yellow crystalline solid with a melting point of $220-222.5^{\circ} \mathrm{C}$. Purity assays indicated that the compound was $100 \%$ active base. The structure of ripazepam is shown in Fig. 1.

Animals and housing. Barrier raised animals of both sexes were used. Random bred albino CD strain rats and albino CD1 mice were supplied by Charles River Breeding Laboratories, Wilmington, Massachusetts. The animals were approximately 5 to 6 weeks of age at study initiation. Animal housing and care conformed to recommendations of HEW Publication (NIH) 74-73. Rats were housed individually in stainless-steel wire mesh cages and mice were housed individually in solid bottom suspended cages containing wood shavings as bedding material. The animals were maintained in rooms with controlled temperature and relative humidity with frequent fresh air exchanges and a 12-hr photoperiod. Body weights and feed consumption were measured weekly. From these data, the concentration of drug in the diet was adjusted weekly to compensate for changes in body weight and feed consumption. Drug/diet admixtures were prepared fresh each week and were offered ad libitum. Fresh water was freely 


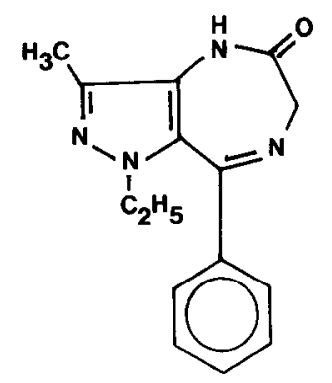

FIG. 1. Structural formula of ripazepam.

available. All animals were observed daily for signs of toxic reactions. Physical examinations were performed weekly at the time of transfer of animals to clean cages. Ophthalmic examinations were performed pretest and at intervals of 1 to 3 months during the study.

Experimental groups. Dose levels selected for these experiments were based on an overall assessment of the effects found in previous acute, subacute, and 1-year oral feeding studies. Groups of 50 rats and 50 mice of each sex were fed ripazepam at 15 and $150 \mathrm{mg} / \mathrm{kg}$ body wt. Additional groups of 50 rats and 50 mice of each sex served as untreated controls.

Pathology studies. Animals found moribund or in an extreme debilitated condition were killed for humane reasons and to minimize the onset of autolytic changes in the event of death. All animals were necropsied and those killed because of debilitating clinical condition were considered deaths for the purposes of data analysis. For animals killed at termination of the study, organ weights and organ to body weight ratios were determined for brain and liver. Following gross examinations, all major organs and gross abnormalities were processed from all animals and evaluated microscopically.

Methods of tumor analysis. All tumors including those noted upon gross examination were subjected to microscopic confirmation. The procedure for analyzing the tumor incidence in both species has been described elsewhere (de la Iglesia $e t$ al., 1981). Briefly, tumor analysis employed a life-table technique to analyze the occurrence of tumors and estimate differences in significance and probability levels between test groups. This technique considers timeresponse data, tumor induction, and correction for extraneous deaths. Tumor incidence was evaluated also using Fisher's Exact Test in both species and the Armitage DoseTrend test in rats.

\section{RESULTS}

\section{Clinical Observations and Nonneoplastic Le- sions}

Survival curves for mice and rats fed ripazepam are shown in Figs. 2 and 3, respectively. A sufficient number of animals was available for statistical analysis at the completion of the studies.

There were no significant clinical signs or ophthalmologic findings in either mice or rats. Body weight gain was suppressed by $21 \%$ in male and $36.4 \%$ in female rats given $150 \mathrm{mg}$ ripazepam $/ \mathrm{kg}$ indicating that maximally tolerable concentrations were administered. Feed consumption was decreased slightly $(7 \%)$ only in female rats at the $150-\mathrm{mg} / \mathrm{kg}$ dose. In treated mice, body weight gain exceeded that of untreated controls at both doses in females and at the $15-\mathrm{mg} / \mathrm{kg}$ dose in the males. Feed consumption was not significantly different between treated and control mice. At necropsy, the mean weight of the liver of male mice was significantly increased at the $150-\mathrm{mg} / \mathrm{kg}$ dose level compared to that of untreated control mice (Table 1). In rats, weights of the liver

TABLE 1

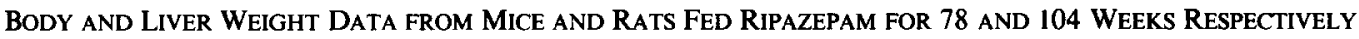

\begin{tabular}{|c|c|c|c|c|c|}
\hline \multirow[b]{2}{*}{ Species } & \multirow{2}{*}{$\begin{array}{c}\text { Dose } \\
(\mathrm{mg} / \mathrm{kg})\end{array}$} & \multicolumn{2}{|c|}{ Liver weight $^{a}$} & \multicolumn{2}{|c|}{ Body weight ${ }^{a}$} \\
\hline & & Males & Females & Males & Females \\
\hline \multirow[t]{3}{*}{ Mouse } & 0 & $7.61 \pm 0.36$ & $6.45 \pm 0.23$ & $45.29 \pm 1.38$ & $37.97 \pm 0.88$ \\
\hline & 15 & $6.49 \pm 0.37$ & $7.69 \pm 0.28$ & $49.22 \pm 1.99$ & $40.58 \pm 1.33$ \\
\hline & 150 & $13.86 \pm 1.58^{*}$ & $7.63 \pm 0.62$ & $44.78 \pm 0.80$ & $39.56 \pm 1.12$ \\
\hline \multirow[t]{3}{*}{ Rat } & 0 & $4.38 \pm 0.11$ & $5.80 \pm 0.21$ & $571.46 \pm 10.31$ & $440.85 \pm 10.99$ \\
\hline & 15 & $5.21 \pm 0.15^{*}$ & $6.00 \pm 0.17$ & $544.20 \pm 15.10$ & $445.06 \pm 11.40$ \\
\hline & 150 & $7.53 \pm 0.23^{*}$ & $7.87 \pm 0.29$ & $505.84 \pm 9.99^{*}$ & $350.22 \pm 14.90^{*}$ \\
\hline
\end{tabular}

${ }^{a}$ Values expressed in $\mathrm{g}$ (body weights) or $\mathrm{g} \%$ (liver weights), mean $\pm \mathrm{SE}$.

* Values significantly different from control $(p<0.01)$. 


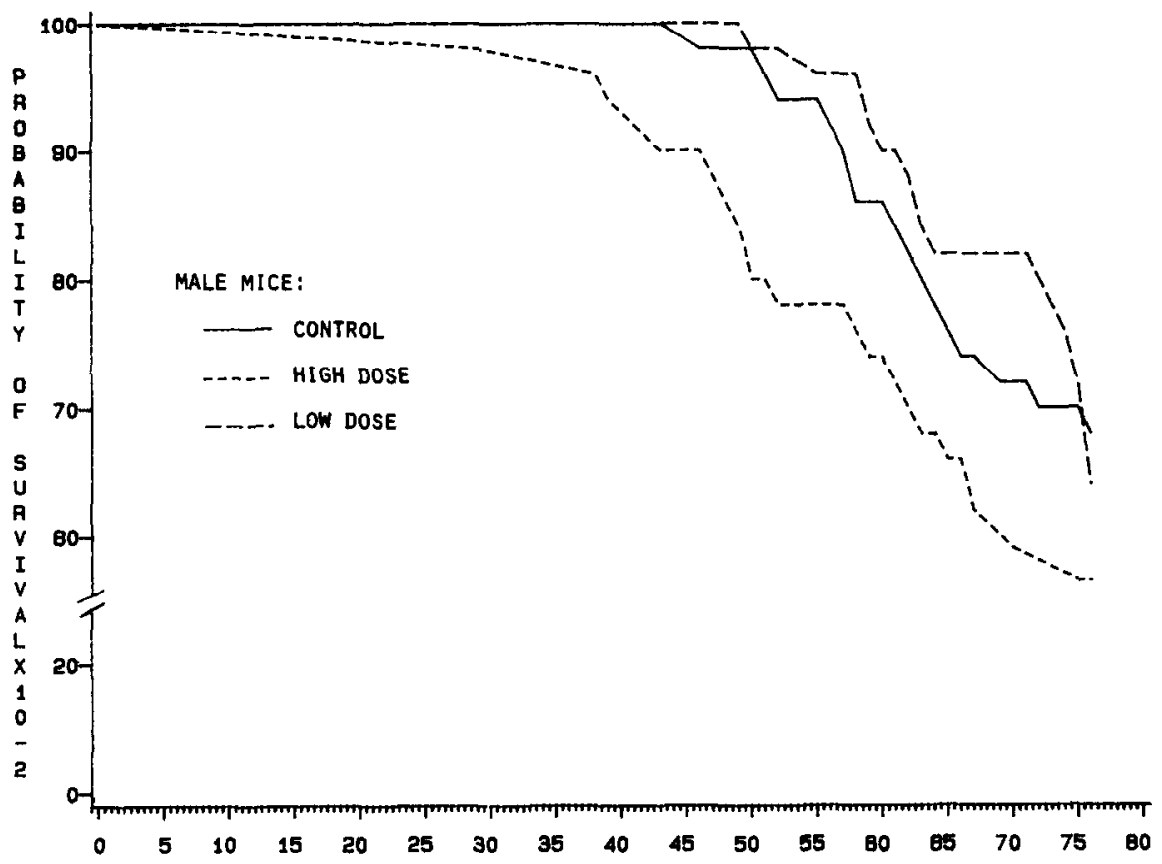

TIME OF STUDY (WEEkS)

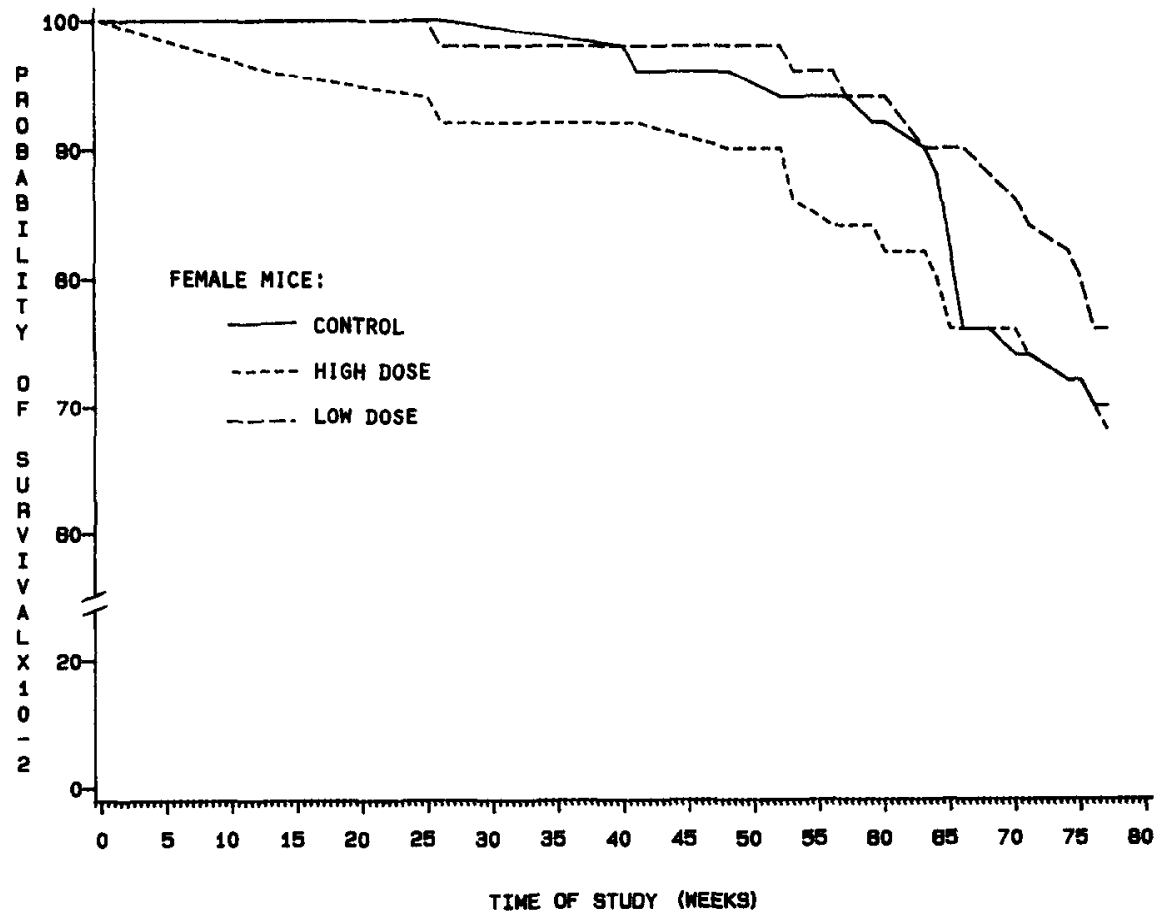

FIG. 2. Probability of survival of mice given ripazepam in the diet for 78 weeks. 

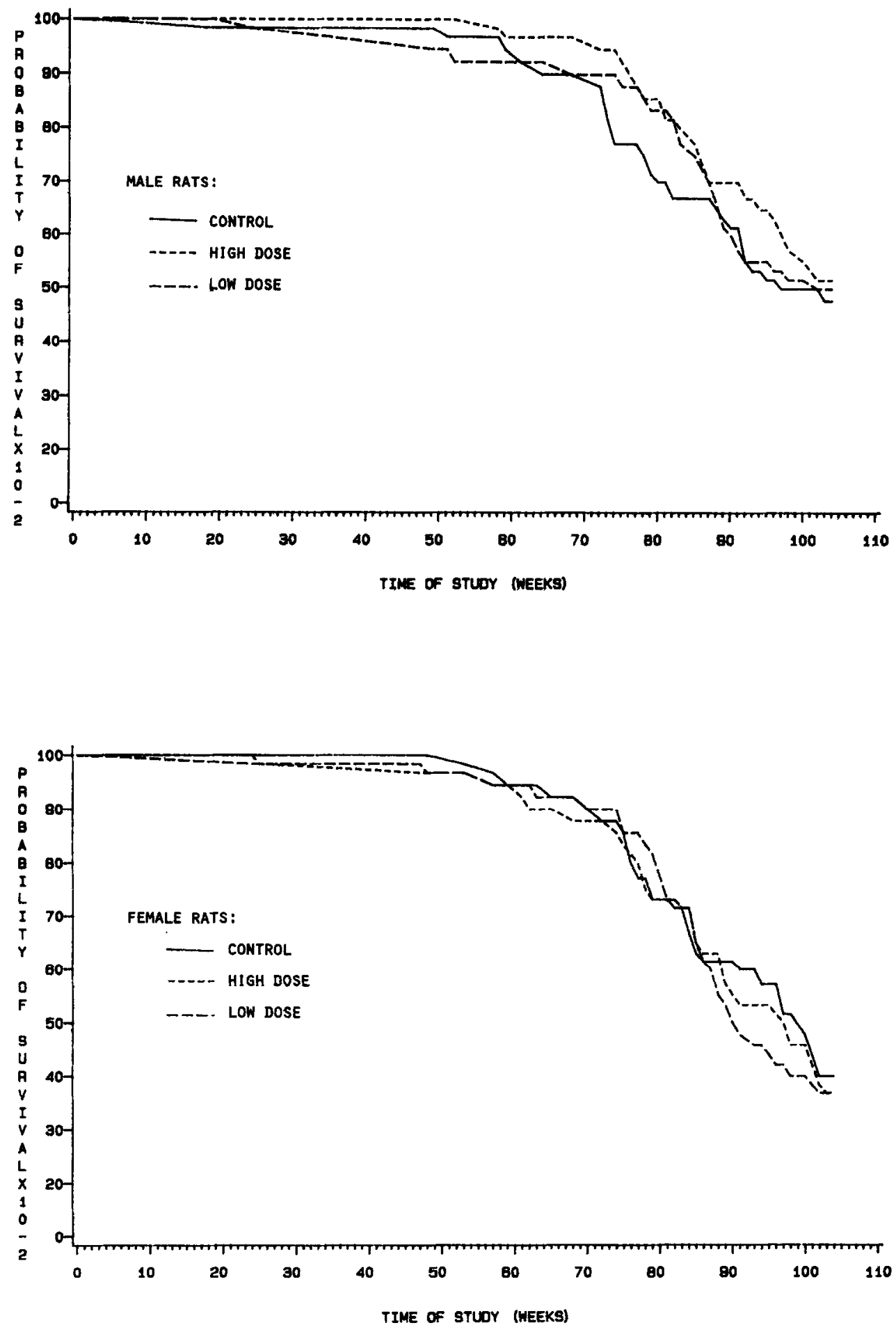

FIG. 3. Probability of survival of rats given ripazepam in the diet for 104 weeks. 
TABLE 2

Distribution OF TUMOR TyPES IN MICE GIVEN RIPAZEPAM ORALLY FOR 78 WEEKS

\begin{tabular}{|c|c|c|c|c|c|c|}
\hline \multirow{2}{*}{$\begin{array}{r}\text { Sex: } \\
\text { Dose }(\mathrm{mg} / \mathrm{kg}) \text { : } \\
\text { Organ/tumor type }\end{array}$} & \multicolumn{3}{|c|}{ Males } & \multicolumn{3}{|c|}{ Females } \\
\hline & 0 & 15 & 150 & 0 & 15 & 150 \\
\hline \multicolumn{7}{|l|}{ Adrenal } \\
\hline Cortical adenoma & 4 & 3 & 3 & 0 & 0 & 1 \\
\hline \multicolumn{7}{|l|}{ Esophagus } \\
\hline $\begin{array}{l}\text { Squamous cell } \\
\text { carcinoma } \\
\text { Liver }\end{array}$ & 0 & 0 & 0 & 0 & 0 & 1 \\
\hline $\begin{array}{l}\text { Liver } \\
\text { Hemangiosarcoma }\end{array}$ & 0 & 0 & 0 & 0 & 0 & 1 \\
\hline $\begin{array}{l}\text { Adenoma (neoplastic } \\
\text { nodule) }\end{array}$ & & & & & & \\
\hline Carcinoma & 0 & $\begin{array}{r}15 \\
0\end{array}$ & $\begin{array}{r}33 \\
1\end{array}$ & $\begin{array}{l}3 \\
0\end{array}$ & $\begin{array}{l}2 \\
0\end{array}$ & $\begin{array}{r}11 \\
0\end{array}$ \\
\hline \multicolumn{7}{|l|}{ Lung } \\
\hline Adenoma & 9 & 8 & 5 & 3 & 1 & 1 \\
\hline Carcinoma & 3 & 6 & 2 & 0 & 2 & 3 \\
\hline \multicolumn{7}{|l|}{ Ovary } \\
\hline Cystadenoma & - & - & - & 0 & 1 & 0 \\
\hline \multicolumn{7}{|l|}{ Pituitary } \\
\hline Adenoma & 0 & 0 & 0 & 1 & 1 & 3 \\
\hline \multicolumn{7}{|l|}{ Uterus } \\
\hline Leiomyosarcoma & - & - & - & 0 & 2 & $\mathbf{0}$ \\
\hline Polyp & - & - & - & 2 & 1 & 1 \\
\hline \multicolumn{7}{|l|}{ Intestine } \\
\hline Lymphosarc & 0 & 1 & 0 & 0 & 0 & 0 \\
\hline \multicolumn{7}{|l|}{ Pancreas } \\
\hline Islet cell aden & 0 & 2 & 0 & 0 & 0 & 0 \\
\hline \multicolumn{7}{|l|}{ Prostate } \\
\hline Adenoma & 1 & 0 & 0 & - & - & 一 \\
\hline \multicolumn{7}{|l|}{ General } \\
\hline Lymphoid tumors & 1 & 3 & 2 & 2 & 3 & 2 \\
\hline Leukemia & 0 & 1 & 0 & 0 & 0 & 0 \\
\hline
\end{tabular}

were significantly increased on a dose related basis in males and in females given $150 \mathrm{mg} / \mathrm{kg}$.

A variety of nonneoplastic pathologic changes were observed in both treated and control mice. These lesions were primarily degenerative or inflammatory in nature and most were considered incidental and related to aging. The incidence of atrial thrombosis was $20 \%$ in males of the $150-\mathrm{mg} / \mathrm{kg}$ group compared to $0.8 \%$ in males of the $15-\mathrm{mg} / \mathrm{kg}$ group and $4 \%$ in untreated control males. Atrophy of the ovaries was seen in $90 \%$ of the females of the $150-\mathrm{mg} / \mathrm{kg}$ group in $46 \%$ of the $15-\mathrm{mg} /$ $\mathrm{kg}$ animals and in $54 \%$ of the controls. Other lesions occurred in comparable incidences between treated and control mice.

Microscopically, nonneoplastic changes associated with drug treatment in rats included centrolobular hypertrophy of hepatocytes principally at the $150-\mathrm{mg} / \mathrm{kg}$ dose. Enlarged hepatocytes stained more intensely with eosin and in a few high dose rats the cytoplasm had a hyaline or "ground glass" appearance. Other alterations included increased incidences of focal accumulations of pulmonary alveolar macrophages in both dose groups and dilatation of tubules in the renal cortex and follicular hyperplasia in the thyroid; these last two changes were more common in male rats of the $150-\mathrm{mg} / \mathrm{kg}$ group.

A variety of other lesions occurred in similar incidences in both control and treated rats.

\section{Neoplasms in Mice}

A summary of the various neoplasms found in treated and control mice is given in Table 2. Tumors of the lungs, liver, and lymphoid organs were the most frequently occurring neoplasms in both sexes.

Total tumor incidence and tumor latency data are summarized in Tables 3 and 4 . The incidences of all tumor types, except hepatocellular adenomas, were not statistically different between treated and control groups. Hepatocellular adenomas (also considered as neoplastic nodules) were increased in both sexes given $150 \mathrm{mg} / \mathrm{kg}$ but not in those groups given $15 \mathrm{mg} / \mathrm{kg}$. The increased incidence of hepatic cell tumors was statistically significant $(p<0.05)$ only in the high dose male mice. Latency periods for hepatic and other tumor types were comparable. The incidence of other benign tumors was not significantly increased in the $150-\mathrm{mg} / \mathrm{kg}$ group. No increase in tumors was found in the $15-\mathrm{mg} / \mathrm{kg}$ group. The number of malignant neoplasms was increased in males of the low dose group but this was considered unrelated to compound administration because of the lack of a dose-response relationship.

Hepatocellular adenomas varied from a single small nodule to large masses involving 
TABLE 3

TOTAL TUMOR INCIDENCE IN MICE GIVEN RIPAZEPAM ORALLY FOR 78 WEEKS

\begin{tabular}{|c|c|c|c|c|c|c|}
\hline \multirow{2}{*}{$\begin{array}{r}\text { Sex: } \\
\text { Dose }(\mathrm{mg} / \mathrm{kg}):\end{array}$} & \multicolumn{3}{|c|}{ Males } & \multicolumn{3}{|c|}{ Females } \\
\hline & 0 & 15 & 150 & 0 & 15 & 150 \\
\hline Animals/group & 50 & 50 & 50 & 50 & 50 & 50 \\
\hline $\begin{array}{l}\text { Incidence of all } \\
\text { tumors }^{a}\end{array}$ & 28 & 39 & 46 & 13 & 13 & 24 \\
\hline $\begin{array}{l}\text { Animals with } \\
\text { tumors }\end{array}$ & 24 & 31 & 39 & 12 & 13 & 21 \\
\hline $\begin{array}{l}\text { Animals with } \\
\text { malignant tumors }\end{array}$ & $\begin{array}{r}4 \\
-\end{array}$ & $\begin{array}{c}11 \\
{[4.6302]^{* *}}\end{array}$ & $\begin{array}{c}5 \\
{[0.0161]}\end{array}$ & $\frac{2}{-}$ & $\begin{array}{c}7 \\
{[1.8637]}\end{array}$ & $\begin{array}{c}6 \\
{[1.4006]}\end{array}$ \\
\hline $\begin{array}{l}\text { Animals with } \\
\text { benign tumors }\end{array}$ & $\frac{21}{-}$ & $\begin{array}{c}23 \\
{[0.1882]}\end{array}$ & $\begin{array}{c}36 \\
{[15.3449]^{*}}\end{array}$ & 10 & $\begin{array}{c}6 \\
{[1.9930]}\end{array}$ & $\begin{array}{c}16 \\
{[1.9234]}\end{array}$ \\
\hline
\end{tabular}

' These figures include multiple tumor types found in individual animals, but do not include multiple tumors of the same type. They are not, therefore, true incidences and cannot be expressed as percentages. Statistical determinations were not performed on these figures.

* Significantly different $(p<0.01)$ from control. Chi-square values indicated in brackets.

** Significantly different $(p<0.05)$ from control.

entire lobes. Multiple nodules occurred more frequently in treated than in control mice. Microscopically, a few tumors consisted of nodules of well differentiated but somewhat smaller hepatocytes than those in adjacent normal areas of the liver. Most specimens, however, contained enlarged hepatocytes or a combination of small and large cells (Fig. 4). Hepatocellular adenomas were confined by the liver capsule; neither local invasion nor metastasis occurred (Figs. 5 and 6). One hepatic cell tumor from a male given $150 \mathrm{mg} /$ $\mathrm{kg}$ consisted of sheets of anaplastic cells with vesiculated nuclei and was considered cytologically a carcinoma (Fig. 7).

\section{Neoplasms in Rats}

Data related to tumor types, incidences, and average latency are summarized in Tables 5 , 6 , and 7 . The most frequently occurring neoplasms in both male and female rats were adrenal cortical adenomas, hepatocellular adenomas (neoplastic nodules), and pituitary adenomas. Mammary gland adenomas and fibroepithelial tumors were common in female rats. No significant dose related differences in tumor types, average latency, tumor onset, or in overall tumor incidences between treated and control rats were observed.

\section{DISCUSSION}

From the results of this study it appears that ripazepam does not elicit a tumorigenic potential in rats when administered at a maximally tolerated dose of $150 \mathrm{mg} / \mathrm{kg}$ for 2 years. In mice, a comparable dose given for 18 months resulted in an increased incidence of hepatocellular adenomas, a frequent tumor in this species. The latency period for hepatic tumors was not affected by treatment and other tumor types were not increased significantly in the mouse.

Interestingly, ripazepam produced a similar increase in the weight of the liver in both rodent species, although a tumorigenic response was evoked in the liver only in the mouse and only at a dose of $150 \mathrm{mg} / \mathrm{kg}$.

A 10-fold lower dose of $15 \mathrm{mg} / \mathrm{kg}$ did not increase significantly the number of hepato- 
TABLE 4

Average Latency Period (Weeks) of Most Common Tumors in Mice Fed Ripazepam for 78 Weeks

\begin{tabular}{|c|c|c|c|c|c|c|}
\hline \multirow[b]{3}{*}{ Tumor type } & \multicolumn{6}{|c|}{ Ripazepam dose $(\mathrm{mg} / \mathrm{kg} /$ day $)$} \\
\hline & \multicolumn{2}{|c|}{150} & \multicolumn{2}{|c|}{15} & \multicolumn{2}{|c|}{0} \\
\hline & $\mathbf{M}$ & $\mathrm{F}$ & $\mathbf{M}$ & $\mathbf{F}$ & $\mathbf{M}$ & F \\
\hline \multicolumn{7}{|l|}{ Adrenal } \\
\hline Cortical adenoma & $\begin{array}{c}78 \\
{[78]}\end{array}$ & $\begin{array}{c}78 \\
{[78]}\end{array}$ & $\begin{array}{c}78 \\
{[78]}\end{array}$ & - & $\begin{array}{c}71 \\
{[51]}\end{array}$ & 一 \\
\hline \multicolumn{7}{|l|}{ Lymphoid tumors } \\
\hline Lymphosarcoma & $\begin{array}{c}72 \\
{[72]}\end{array}$ & $\begin{array}{c}74 \\
{[74]}\end{array}$ & $\begin{array}{c}77 \\
{[75]}\end{array}$ & $\begin{array}{c}52 \\
{[26]}\end{array}$ & $\begin{array}{c}57 \\
{[57]}\end{array}$ & $\begin{array}{c}74 \\
{[70]}\end{array}$ \\
\hline \multicolumn{7}{|l|}{ Lung } \\
\hline Adenoma & $\begin{array}{c}76 \\
{[67]}\end{array}$ & $\begin{array}{c}78 \\
{[78]}\end{array}$ & $\begin{array}{c}74 \\
{[60]}\end{array}$ & $\begin{array}{c}78 \\
{[78]}\end{array}$ & $\begin{array}{c}73 \\
{[46]}\end{array}$ & $\begin{array}{c}72 \\
{[65]}\end{array}$ \\
\hline Carcinoma & $\begin{array}{c}74 \\
{[70]}\end{array}$ & $\begin{array}{c}73 \\
{[64]}\end{array}$ & $\begin{array}{c}68 \\
{[55]}\end{array}$ & $\begin{array}{c}74 \\
{[70]}\end{array}$ & $\begin{array}{c}73 \\
{[64]}\end{array}$ & - \\
\hline \multicolumn{7}{|l|}{ Liver } \\
\hline Adenoma & $\begin{array}{c}70 \\
{[43]}\end{array}$ & $\begin{array}{c}77 \\
{[65]}\end{array}$ & $\begin{array}{c}75 \\
{[55]}\end{array}$ & $\begin{array}{c}78 \\
{[78]}\end{array}$ & $\begin{array}{c}77 \\
{[69]}\end{array}$ & $\begin{array}{c}77 \\
{[74]}\end{array}$ \\
\hline Carcinoma/hemangiosarcoma & $\begin{array}{c}78 \\
{[78]}\end{array}$ & $\begin{array}{c}78 \\
{[78]}\end{array}$ & - & - & - & - \\
\hline
\end{tabular}

Onset [in brackets] expressed as week when first tumor detected; average latency expressed as arithmetic mean of onset weeks/tumor bearing animals, $\mathrm{M}$ : males; $\mathrm{F}$ : females.

cellular tumors suggesting a threshold effect. Hepatomegaly has been observed previously in rodents given other diazopinones (Fox and Lahcen, 1974; Kuriyama et al., 1978; de la Iglesia et al., 1981). The increase in liver weight was correlated with an increase in drug metabolizing enzymes and smooth endoplasmic reticulum in hepatic cells (Kuriyama et al., 1978). There was a higher incidence of nonneoplastic changes in the heart and ovaries in mice and in the lung and kidneys in rats, but these lesions are not uncommon in aged rodents and were considered to represent a skewed distribution rather than a direct drug effect.

Only a few reports concerning the carcinogenic potential of benzodiazepines have been published, although these drugs have been used extensively for several years. Hepatic cell adenomas and peliosis hepatis were reported in mice fed up to $0.15 \%$ oxazepam (estimated to yield about $210 \mathrm{mg} / \mathrm{kg}$ ) for a year (Fox and Lahcen, 1974). Data on the chronic administration of oxazepam to rats are not available for comparison purposes. However, closely related compounds such as diazepam and prazepam have been studied for 104 weeks in rats and 80 weeks in mice and neither compound was tumorigenic in either species (de la Iglesia et al., 1981). In other studies, diazepam was without significant effects in rats given doses of up to 240 $\mathrm{mg} / \mathrm{kg}$ for 42 weeks (Randall et al., 1961).

Chlordiazepoxide was administered to rats at doses of up to $240 \mathrm{mg} / \mathrm{kg}$ for most of their life span and the compound was reported to be innocuous. However, no definitive data on tumor incidences were provided (Zbinden et al., 1961).

Carcinogenesis in the rat liver has been reported to be accompanied by focal alterations in such hepatocellular enzymes as ATPase. 


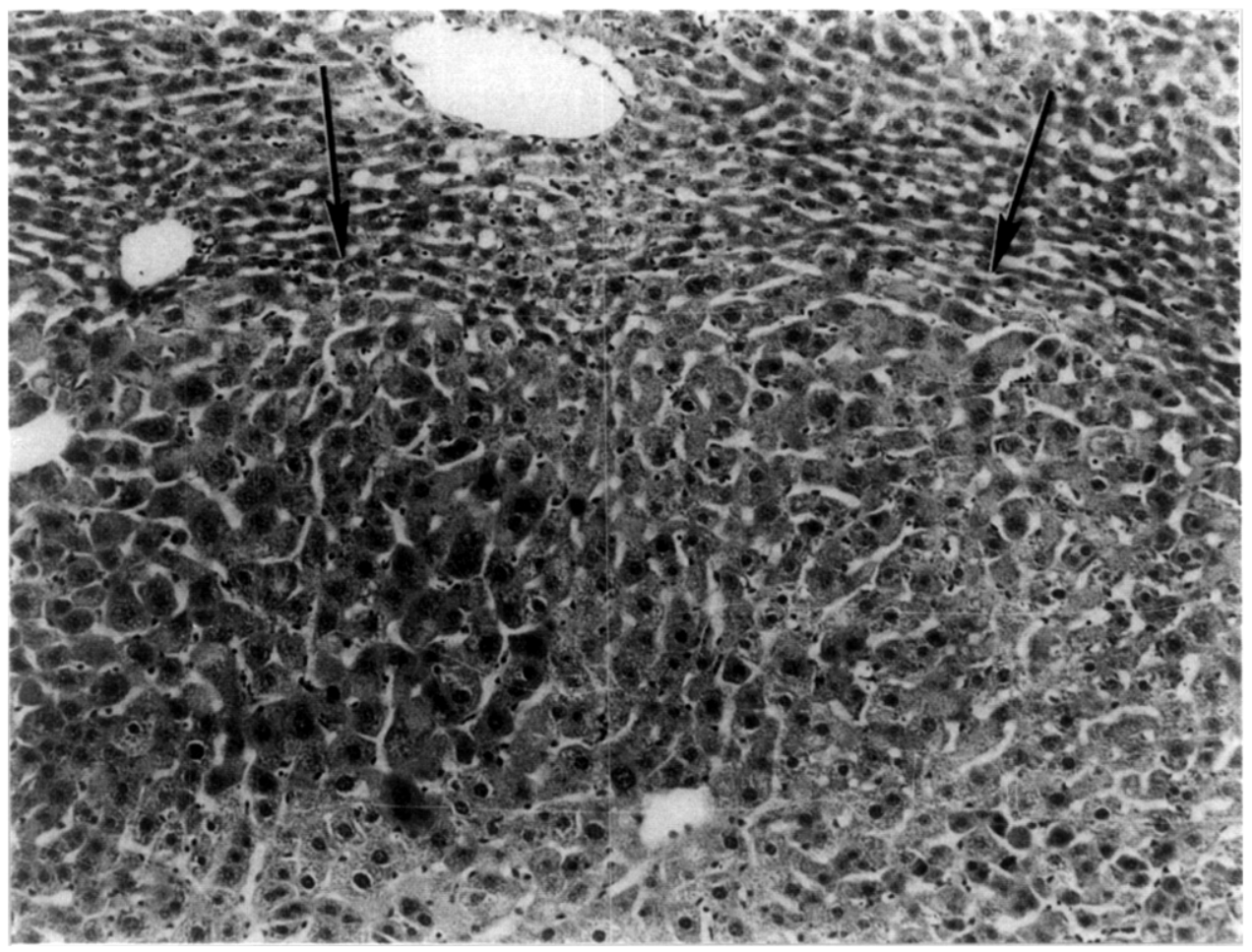

FIG. 4. Liver section from a male mouse fed $150 \mathrm{mg} / \mathrm{kg}$ of ripazepam for 78 weeks. Liver cell adenoma consisting of hypertrophic hepatocytes (arrows) is well delineated from normal parenchyma. $\times 100$.

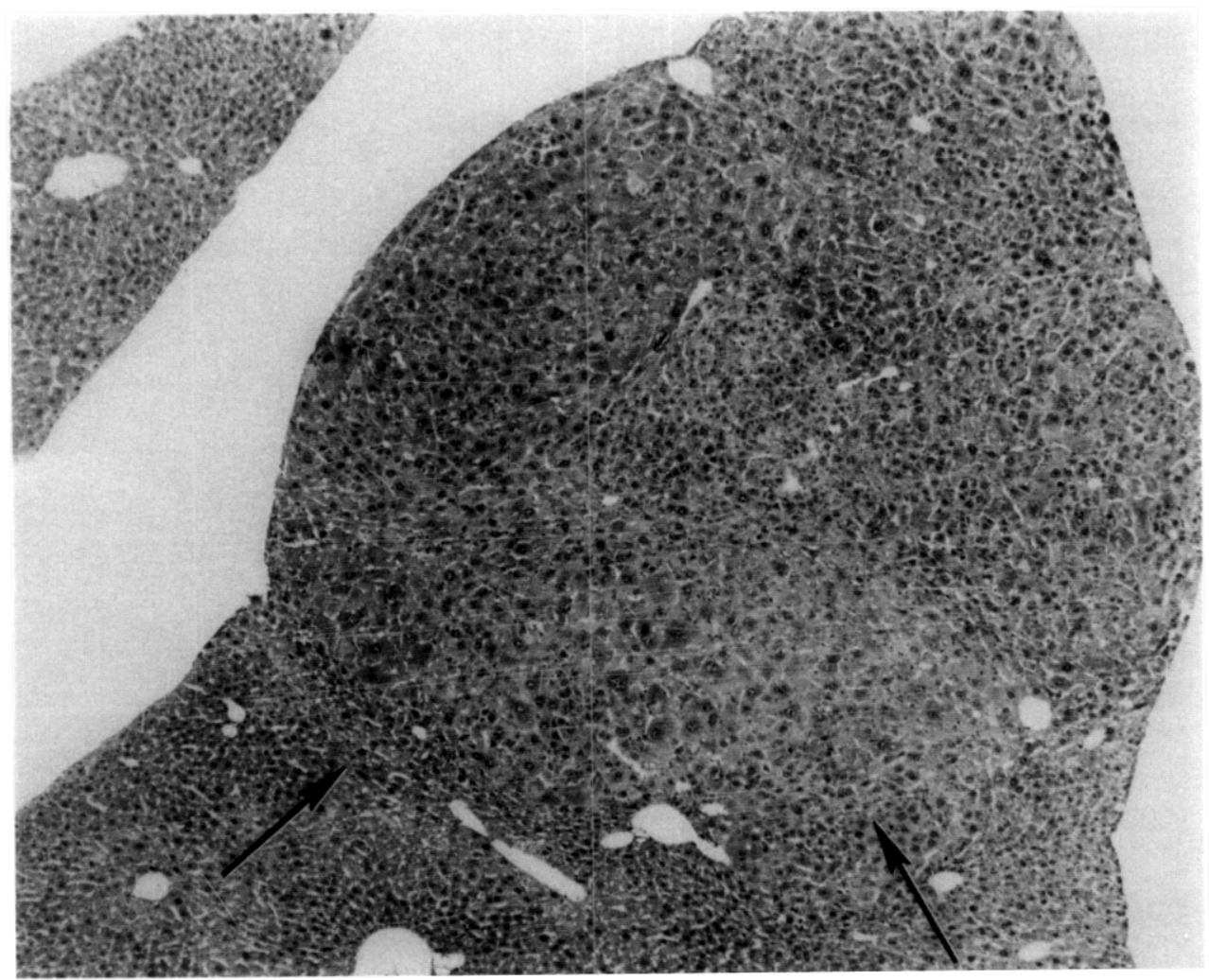

Fig. 5. Hepatocellular adenoma from male mouse fed $150 \mathrm{mg} / \mathrm{kg}$ of ripazepam. Tumor involves a large area of the lobe (arrows) but is confined within the liver capsule. $\times 40$. 


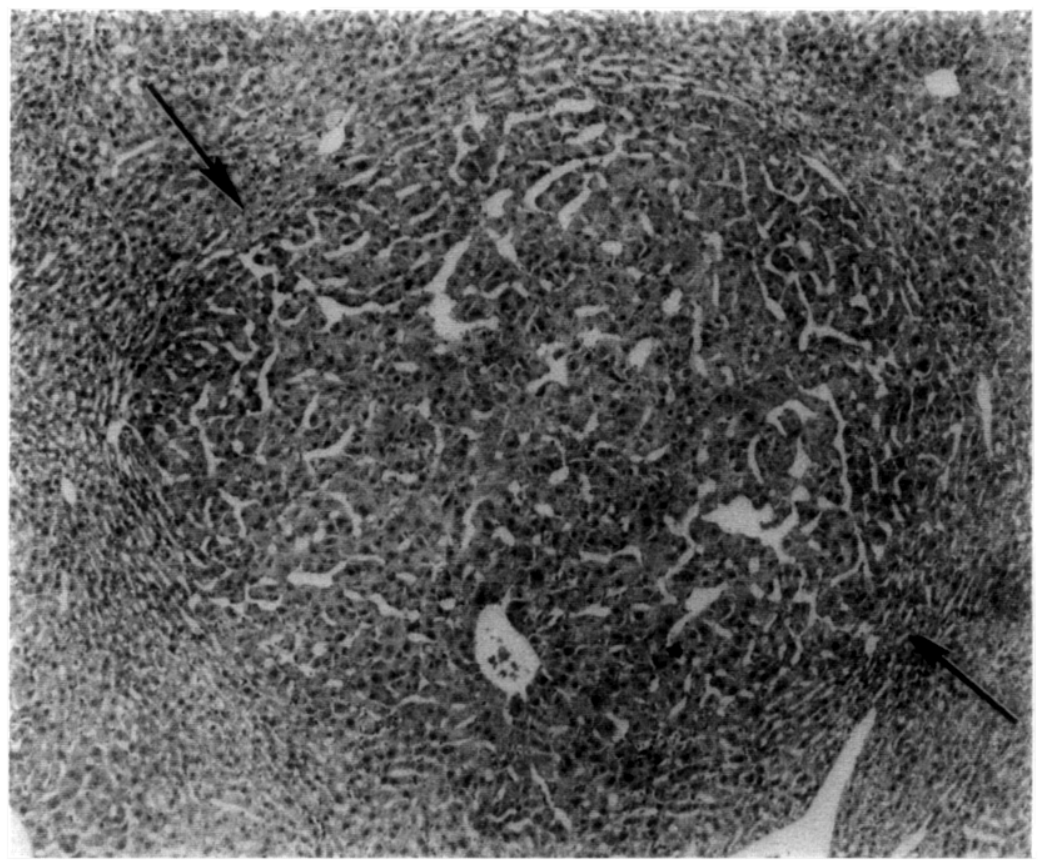

FiG. 6. A small hepatocellular adenoma consisting of cords of enlarged hepatocytes that form a well delineated nodule (arrows). $\times \mathbf{4 0}$.

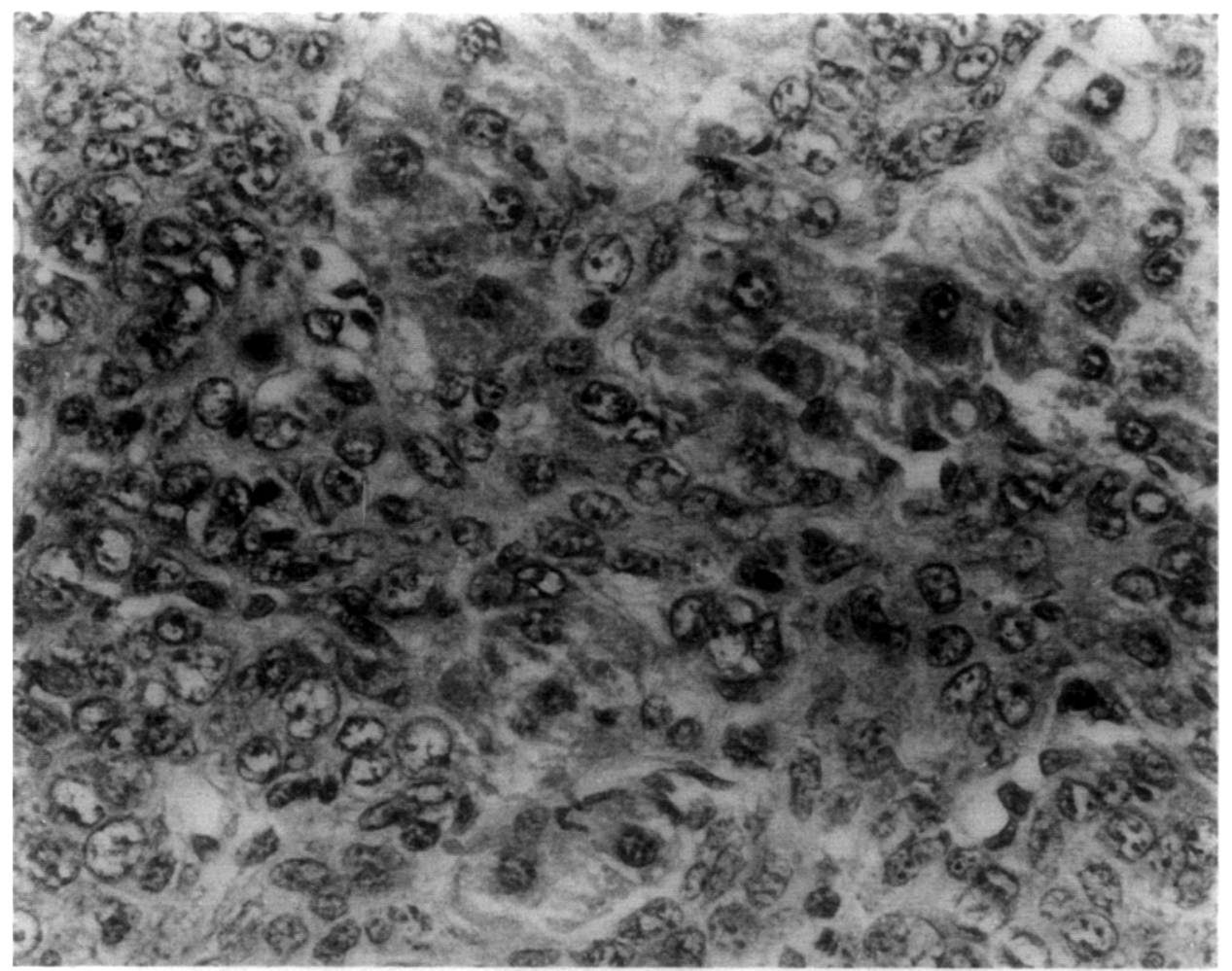

FIG. 7. Hepatocellular carcinoma from a male mouse fed $150 \mathrm{mg} / \mathrm{kg}$ of ripazepam showing sheets of anaplastic hepatocytes with vesiculated nuclei. $\times 250$. 
TABLE 5

Distribution of TUMOR TyPes IN RATS GIVEN RiPAZEPAM ORALLY FOR 104 WEEKS

\begin{tabular}{|c|c|c|c|c|c|c|c|c|c|c|c|c|c|}
\hline \multirow{2}{*}{$\begin{array}{r}\text { Sex: } \\
\text { Dose }(\mathrm{mg} / \mathrm{kg}): \\
\text { Organ/tumor type }\end{array}$} & \multicolumn{3}{|c|}{ Males } & \multicolumn{3}{|c|}{ Females } & \multirow{2}{*}{$\begin{array}{l}\text { Sex: } \\
\mathrm{g} / \mathrm{kg})\end{array}$} & \multicolumn{3}{|c|}{ Males } & \multicolumn{3}{|c|}{ Females } \\
\hline & 0 & 15 & 150 & 0 & 15 & 150 & & 0 & 15 & 150 & 0 & 15 & 150 \\
\hline Adrenal & & & & & & & Carcinoma & 0 & 0 & 1 & 0 & 1 & 0 \\
\hline Cortical adenoma & 4 & 10 & 5 & 10 & 6 & 15 & Squamous cell & & & & & & \\
\hline Cortical carcinoma & 0 & 0 & 0 & 1 & 0 & 0 & carcinoma & 1 & 2 & 0 & 1 & 0 & 0 \\
\hline Pheochromocytoma & 1 & 4 & 0 & 0 & 0 & 1 & Schwann cell tumor & 0 & 0 & 0 & 0 & 0 & 1 \\
\hline Auditory canal & & & & & & & Keratoacanthroma & 1 & 2 & 0 & 0 & 0 & 0 \\
\hline Carcinoma & 0 & 0 & 0 & 0 & 1 & 0 & Subcutis & & & & & & \\
\hline Cervix & & & & & & & Lymphoma & 2 & 0 & 0 & 0 & 0 & 0 \\
\hline Leiomyoma & 0 & 0 & 0 & 0 & 0 & 1 & Fibroma & 2 & 1 & 3 & 0 & 1 & 0 \\
\hline Intestine & & & & & & & Fibrosarcoma & 0 & 0 & 1 & 0 & 1 & 0 \\
\hline Fibrosarcoma & 0 & 0 & 0 & 1 & 0 & 0 & Neurofibrosarc & 0 & 1 & 0 & 0 & 0 & 0 \\
\hline Neurofibroma & 0 & 1 & 0 & 0 & 0 & 0 & Sarco & 1 & 0 & 4 & 1 & 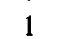 & 1 \\
\hline Kidney & & & & & & & Angiosarco & 0 & 0 & 1 & 0 & $v$ & 0 \\
\hline Adenoma & 0 & 0 & 0 & 0 & 0 & 1 & Lipoma & 0 & 0 & 1 & 0 & 0 & 0 \\
\hline Carcinoma & 1 & 0 & 0 & 0 & 0 & 1 & Thymus & & & & & & \\
\hline Nephroblastoma & 1 & 0 & 0 & 0 & 0 & 0 & Lymphoma & 1 & $\mathbf{0}$ & 0 & 0 & 0 & 1 \\
\hline Giver & & & & & & & Thyroid & & & & & & \\
\hline Adenoma ( $\mathrm{n}$ & & & & & & & Ad & 5 & 5 & 2 & 2 & 0 & 1 \\
\hline no & 5 & 4 & 9 & 4 & 6 & 6 & $\mathrm{Ca}$ & 0 & o & 1 & 0 & 0 & 1 \\
\hline Carci & 0 & 0 & 1 & 0 & 0 & 2 & Uterus & & & & & & \\
\hline jiosarco & 0 & 0 & 0 & 0 & 0 & 1 & Papilloma & - & - & - & 3 & 1 & 2 \\
\hline Hemangioma & 1 & 0 & 0 & 0 & 0 & 0 & $\mathrm{Ca}$ & - & - & - & 1 & 0 & 0 \\
\hline Lung & & & & & & & Leiom & - & - & - & 1 & 0 & 0 \\
\hline Adeno & 2 & 1 & 0 & 0 & 1 & 0 & Testis & & & & & & \\
\hline Aden & 0 & 0 & 0 & 1 & 2 & 0 & Inters & 1 & 1 & 1 & - & - & - \\
\hline Mamma & & & & & & & Parathyroid & & & & & & \\
\hline Adenoma & 1 & 0 & 0 & 13 & 17 & 10 & Adenoma & 1 & 2 & 2 & 0 & 1 & 1 \\
\hline $\mathrm{Ad}$ & 0 & 0 & 0 & 2 & 0 & 5 & Brain & & & & & & \\
\hline Fibro & 1 & 1 & 1 & 32 & 23 & 28 & A & 0 & 1 & 0 & 0 & 0 & 0 \\
\hline Fibro & 0 & 0 & 0 & 1 & 0 & 0 & Epend & 0 & 1 & 0 & 0 & 0 & 0 \\
\hline Medias & & & & & & & Musc & & & & & & \\
\hline Neurofibrosarcoma & 0 & 1 & 0 & 0 & 0 & 0 & Rhabdomyo & 0 & 1 & 0 & 0 & 0 & 0 \\
\hline Lymph node & & & & & & & Nerve & & & & & & \\
\hline Lymphoma & 0 & 0 & 1 & 0 & 0 & 0 & Glioma & 0 & 1 & 0 & 0 & 0 & 0 \\
\hline Peritoneal cavit & & & & & & & Spleen & & & & & & \\
\hline Lymphoma & 1 & 0 & 0 & 0 & 0 & 0 & Histio & 0 & 0 & 1 & 0 & 0 & 0 \\
\hline Sarc & 0 & 0 & 0 & 1 & 1 & 0 & Sar & 0 & 1 & 0 & 0 & 0 & 0 \\
\hline Pituitary & & & & & & & Hemangioendothelioma & 1 & 0 & 0 & 0 & 0 & 0 \\
\hline Adenoma & 20 & 28 & 36 & 36 & 38 & 37 & Unknown & & & & & & \\
\hline Sebaceous glan & & & & & & & Neurofibroma & 0 & 0 & 1 & 0 & 0 & 0 \\
\hline Adenoma & 0 & 0 & 0 & 2 & 1 & 1 & Pancre & & & & & & \\
\hline Carcinoma & 0 & 0 & 0 & 0 & 1 & 0 & Islet cell & 2 & 2 & 3 & 0 & 1 & 0 \\
\hline ikin & & & & & & & Gen & & & & & & \\
\hline Papilloma & 0 & 2 & 0 & 0 & 0 & 0 & Leukemia & 0 & 1 & 0 & 0 & 0 & 0 \\
\hline
\end{tabular}

Diethylnitrosamine administration resulted in an increase in ATPase deficient foci in the liver of rats but not mice (Laib et al., 1982). In a similar assay for tumor promoting effects in the liver, rats were fed 3 '-methyl-4-(dimethylamino)azobenzene at a concentration of $0.06 \%$ for 3 weeks followed by $0.05 \%$ diazepam for an additional 13 weeks. Diazepam 
TABLE 6

TOTAL Tumor INCIDENCE IN RATS GIVEN RIPAZEPAM ORALly FOR 104 WEeKS

\begin{tabular}{|c|c|c|c|c|c|c|}
\hline \multirow{2}{*}{ Dose $(\mathrm{mg} / \mathrm{kg}):{ }^{\text {Sex: }}$} & \multicolumn{3}{|c|}{ Males } & \multicolumn{3}{|c|}{ Females } \\
\hline & 0 & 15 & 150 & 0 & 15 & 150 \\
\hline Animals/group & 50 & 50 & 50 & 50 & 50 & 50 \\
\hline Incidence of all tumors ${ }^{a}$ & 58 & 74 & 76 & 142 & 119 & 131 \\
\hline Animals with tumors & 40 & 43 & 47 & 48 & 47 & 46 \\
\hline $\begin{array}{l}\text { Animals with } \\
\text { malignant tumors }\end{array}$ & $\begin{array}{l}7 \\
-\end{array}$ & $\begin{array}{c}10 \\
{[1.0395]}\end{array}$ & $\begin{array}{c}10 \\
{[1.1640]}\end{array}$ & $\begin{array}{r}9 \\
-\end{array}$ & $\begin{array}{c}7 \\
{[0.0519]}\end{array}$ & $\begin{array}{c}11 \\
{[2.5032]}\end{array}$ \\
\hline $\begin{array}{l}\text { Animals with } \\
\text { benign tumors }\end{array}$ & 36 & $\begin{array}{c}40 \\
{[0.0000]}\end{array}$ & $\begin{array}{c}45 \\
{[0.3057]}\end{array}$ & $\begin{array}{l}45 \\
-\end{array}$ & $\begin{array}{c}43 \\
{[0.0000]}\end{array}$ & $\begin{array}{c}44 \\
{[0.0259]}\end{array}$ \\
\hline
\end{tabular}

${ }^{a}$ These figures include multiple tumor types found in individual animals, but do not include multiple tumors of the same type. They are not, therefore, true incidence and cannot be expressed as percentages. Statistical determinations were not performed on these figures.

${ }^{b}$ Chi-squares values indicated in brackets; values not significantly different from control.

did not increase the number or size of ATPase deficient foci in the liver indicating that the compound was not a promoter of hepatocarcinogenesis in the rat (Hino and Kitagawa, 1982). In other short term assays diazepam, clorazepate, oxazepam, and lorazepam did not initiate preneoplastic or neoplastic foci in the liver when administered orally to rats for 14 weeks. Further, these diazepines did not promote or enhance the neoplastic foci initiated in the livers of rats with $\mathrm{N}$-2-fluorenylacetamide (Mazue et al., 1982). Thus, most available reports on the chronic administration of benzodiazepines suggest that these compounds are not tumorigenic. Perhaps this failure to induce hepatic cell or other neoplasms is related to the extensive biotransformation of the compounds by hepatocytes (Viau et al., 1972, 1973). We have investigated the possibility that these tumors be the result of direct genotoxic insult, and ripazepam did not induce revertants in the standard bacterial plate assay with five strains of Salmonella typhimurium (unpublished data). Several benzodiazepines have been evaluated for potential mutagenicity with equivocal results, including diazepam and oxazepam which were not mutagenic in bacterial assays with four salmonella strains (Balbi et al., 1980). The urine of mice treated with diazepam, however, was reported to increase revertants in two strains of salmonella (Batzinger et al., 1978). No chromosomal aberrations or breaks have been found in several in vitro, in vivo animal or human studies with diazepines (Staiger, 1969, 1970; White, 1974; Neda et al., 1977; Schmid and Staiger, 1969; Cohen et al., 1969). However, chlordiazepoxide was reported to induce sex-linked recessive lethality and translocation in drosophila (Sanjeeva Rao and Pratays, 1974), and increased dominant lethality in mice (Prabhakar Rao and Sanjeeva Rao, 1977), whereas diazepam produced chromosomal breaks in mouse bone marrow cells (Petersen et al., 1978).

The benzodiazepines are compounds with similar pharmacological properties and the collective evaluation of experimental studies yields equivocal results. Based on the results of this study with ripazepam and published data on related compounds it appears that the structural similarities of these compounds are not predictive of the potential for tumor induction in rodents, nor are these effects clearly elucidated in mechanistic studies using genetic endpoints (de la Iglesia et al., 1981; Mazue et al., 1982). 
TABLE 7

EARLiest ONSET AND AVERAGe LATENCY Period of COMmon Tumors IN RATS FED RIPAZEPAM FOR 104 WEEKS

\begin{tabular}{|c|c|c|c|c|c|c|}
\hline \multirow[b]{3}{*}{ Tumor type } & \multicolumn{4}{|c|}{ Ripazepam dose (mg/kg/day) } & & \\
\hline & \multicolumn{2}{|c|}{150} & \multicolumn{2}{|c|}{15} & \multicolumn{2}{|c|}{ Controls } \\
\hline & $\mathbf{M}$ & $\mathbf{F}$ & $\mathbf{M}$ & $\mathbf{F}$ & $\mathbf{M}$ & $\mathbf{F}$ \\
\hline \multicolumn{7}{|l|}{ Pituitary } \\
\hline Adenoma & $\begin{array}{c}94 \\
{[59]}\end{array}$ & $\begin{array}{c}93 \\
{[47]}\end{array}$ & $\begin{array}{c}95 \\
{[47]}\end{array}$ & $\begin{array}{c}94 \\
{[70]}\end{array}$ & $\begin{array}{c}90 \\
\text { [59] }\end{array}$ & $\begin{array}{c}92 \\
{[53]}\end{array}$ \\
\hline Basophil adenoma & $\begin{array}{c}104 \\
{[104]}\end{array}$ & - & - & - & $\begin{array}{c}73 \\
{[73]}\end{array}$ & - \\
\hline \multicolumn{7}{|l|}{ Liver } \\
\hline Adenoma & $\begin{array}{l}100 \\
{[81]}\end{array}$ & $\begin{array}{l}100 \\
{[89]}\end{array}$ & $\begin{array}{c}99 \\
{[85]}\end{array}$ & $\begin{array}{c}96 \\
{[78]}\end{array}$ & $\begin{array}{c}99 \\
{[92]}\end{array}$ & $\begin{array}{c}97 \\
{[82]}\end{array}$ \\
\hline Carcinoma & $\begin{array}{c}83 \\
{[83]}\end{array}$ & $\begin{array}{c}91 \\
{[78]}\end{array}$ & - & - & - & - \\
\hline \multicolumn{7}{|l|}{ Pancreas } \\
\hline Acinar cell adenoma & $\begin{array}{c}104 \\
{[104]}\end{array}$ & - & $\begin{array}{c}104 \\
{[104]}\end{array}$ & - & - & - \\
\hline Islet cell adenoma & $\begin{array}{c}84 \\
{[77]}\end{array}$ & - & $\begin{array}{c}98 \\
{[92]}\end{array}$ & $\begin{array}{c}104 \\
{[104]}\end{array}$ & $\begin{array}{l}101 \\
\text { [97] }\end{array}$ & - \\
\hline \multicolumn{7}{|l|}{ Mammary gland } \\
\hline Adenoma & - & $\begin{array}{c}78 \\
{[58]}\end{array}$ & - & $\begin{array}{c}77 \\
{[48]}\end{array}$ & $\begin{array}{c}13 \\
{[13]}\end{array}$ & $\begin{array}{r}79 \\
{[51]}\end{array}$ \\
\hline Adenocarcinoma & - & $\begin{array}{c}48 \\
{[26]}\end{array}$ & - & - & - & $\begin{array}{c}70 \\
{[42]}\end{array}$ \\
\hline Fibroepithelial tumor & $\begin{array}{c}104 \\
{[104]}\end{array}$ & $\begin{array}{c}68 \\
{[23]}\end{array}$ & $\begin{array}{c}64 \\
{[64]}\end{array}$ & $\begin{array}{c}71 \\
{[39]}\end{array}$ & $\begin{array}{c}103 \\
{[103]}\end{array}$ & $\begin{array}{c}72 \\
{[42]}\end{array}$ \\
\hline \multicolumn{7}{|l|}{ Adrenals } \\
\hline Cortical adenoma & $\begin{array}{l}100 \\
{[85]}\end{array}$ & $\begin{array}{c}98 \\
{[62]}\end{array}$ & $\begin{array}{c}92 \\
{[52]}\end{array}$ & $\begin{array}{c}98 \\
{[81]}\end{array}$ & $\begin{array}{c}104 \\
{[104]}\end{array}$ & $\begin{array}{c}92 \\
{[75]}\end{array}$ \\
\hline Pheochromocytoma & - & $\begin{array}{c}97 \\
{[97]}\end{array}$ & $\begin{array}{c}91 \\
\text { [75] }\end{array}$ & - & $\begin{array}{c}64 \\
{[64]}\end{array}$ & - \\
\hline Cortical carcinoma & - & - & - & - & - & $\begin{array}{c}102 \\
{[102]}\end{array}$ \\
\hline \multicolumn{7}{|l|}{ Thyroid } \\
\hline Follicular adenoma & $\begin{array}{c}96 \\
{[87]}\end{array}$ & $\begin{array}{c}104 \\
{[104]}\end{array}$ & $\begin{array}{c}91 \\
{[83]}\end{array}$ & - & $\begin{array}{l}102 \\
{[92]}\end{array}$ & $\begin{array}{c}94 \\
{[84]}\end{array}$ \\
\hline Carcinoma & $\begin{array}{c}104 \\
{[104]}\end{array}$ & $\begin{array}{c}104 \\
{[104]}\end{array}$ & - & - & - & - \\
\hline \multicolumn{7}{|l|}{ Testis } \\
\hline Interstitial cell tumor & $\begin{array}{c}104 \\
{[104]}\end{array}$ & - & $\begin{array}{c}104 \\
{[104]}\end{array}$ & 一 & $\begin{array}{c}104 \\
{[104]}\end{array}$ & - \\
\hline
\end{tabular}

Note. Onset [in brackets] expressed as week when first tumor detected; average latency expressed as arithmetic mean of onset weeks/tumor bearing animals; $M$, males, $F$, females. 


\section{REFERENCES}

Balbi, A., Muscettalo, G., Staiano, N., Martire, G., AND DE LORENZO, F. (1980). Psychotropic drugs: Evaluation of mutagenic effects. Pharmacol Res. Commun. 12, 423-432.

Batzinger, R. P., Ou, Suh-Yun L., And Bueding, E. (1978). Antimutagenic effects of 2 (3) -test-butyl-4-hydroxyanisole and of antimicrobial agents. Cancer Res. 38, 4478-4485.

Cohen, M. M., Hikschnorn, K., and Frosch, W. (1969). Cytogenetic effects of tranquilizing drugs in vivo and in vitro. $J$. Amer. Med. Assoc. 207, 2425.

Fox, K. A., AND LAHCEN, R. B. (1974). Liver cell adenomas and peliosis hepatis in mice associated with oxazepam. Res. Commun. Chem. Pathol. Pharmacol. 8, 481-488.

FoX, K. E. (1975). Benzodiazepines, reproduction and development. Psychopharmacol. Bull. 11, 41-42.

Guerriero, F. J., AND Fox, K. A. (1976). Benzodiazepines and reproduction of Swiss-Webster mice. Res. Commun. Chem. Pathol. Pharmacol. 13, 601-610.

IIINO, O., AND KITAGAWA, T. (1982). Effect of diazepam on hepatocarcinogenesis in the rat. Toxicol. Lett. 11, 155-157.

de la Iglesia, F. A., Barsoum, N., Gough, A., Mitchell, L., Martin, R. A., Difonzo, C., AND MCGuire, E. J. (1981). Carcinogenesis bioassay of prazepam (verstran) in rats and mice. Toxicol. Appl. Pharmacol. 57, 39-54.

Kuriyama, T., Nishigalsi, K., Kakishita, T., AOlSi, M., SUZUKI, H., AND OTANI, G. (1978). Safety studies of prazepam (K-373) II. Subacute toxicity study of prazepam in rats. Ohyo Yakusi 15, 247-268.

LAIB, R. J., BROCKes, B., SCHWAIER, A., AND HOLT, H. M. (1982). Strain and species differences in the induction of ATPase deficient hepatic foci by diethylnitrusamine. Cancer Lett. 15, 145-148.

Mazue, G., Remaindet, B., Gouy, D., Berthe, J., RoNCUCCI, R., AND WILliams, G. M. (1982). Limited in vivo bioassays on some benzodiazepines: Lack of experimental initiating or promoting effect of the benzodiazepine tranquillizers diazepam, clorazepate, oxazepam and lorazepam. Arch. Int. Pharmacodyn. Ther. 257, 59-64.

Neda, K., Yamamoto, K., Sato, H., Sawai, M., and ISHIMURA, K. (1977). In vivo cytogenetic studies of 10chloro-11b-(2-fluorophenyl)-7-(2-hydroxyethyl)-2,3, 5,11 b-tetrahydrooxazolo- $(3,2-d)(1,4)$ benzodiazepine -
6(7H)-one(MS-4101) on rat bone marrow cells. Folia Pharmacol. Japan 73, 651-656.

Petersen, K. W., Sherwood, H. L., and Petersen, H. (1978). Cytogenetic effects of diazepam and chlordiazepoxide. Anat. Rec. 190, 620.

Poschel, P. B. H., McCarthy, D. A., Chen, G., And Ensor, C. R. (1974). Pyrazapon (Cl-683): A new antianxiety agent. Psychopharmacologia 35, 257-271.

Prabhakar RaO, K., and Sanjeeva RaO, M. (1977). Induction of dominant lethal mutations in mice with chlordiazepoxide hydrochloride. Indian J. Med. Res. 66, 847-851.

Randall, L. O., Heise, G. A., Schallek, W., Bagdon, R. E., BANziger, R., Boris, A., MOE, R. A., AND ABrams, W. B. (1961). Pharmacological and clinical studies on valium (TM), a new psychotherapeutic agent of the benzodiazepine class. Curr. Ther. Res. 3, 405425.

RANDall, L. O., SChaller, W., STERnBaCh, L. H., AND NING, R. Y. (1974). Chemistry and pharmacology of the 1,4-Benzodiazepines. In Medicinal Chemistry Monograph. Vol. 4-III, Psychopharmacological Agents III (M. Gordon, ed.), pp. 175-281. Academic Press, New York.

Sanjeeva RaO, M., and Pratays, C. (1974). Genetic effects of Chlordiazepoxide in Drosophilia melanogaster. Indian J. Herslitz. 6, 87.

SCHMID, W., AND STAIGER, G. R. (1969). Chromosome studies on bone marrow from Chinese hamsters treated with benzodiazepine tranquilizers and cyclophosphamide. Mutat. Res. 7, 99-108.

StaIGER, G. R. (1969). Chlordiazepoxide and diazepam: Absence of effects on the chromosomes of diploid human fibroblast cells. Mutat. Res. 7, 109

STAIGER, G. R. (1970). Studies on the chromosomes of human lymphocytes treated with diazepam in vitro. Mutat. Res. 10, 635-644.

Viau, J. P., Epps, J. E., and DiCarlo, F. J. (1972). Prazepam metabolism in vitro. Biochem. Pharmacol. 21, 563-569.

Viau, J. P., Epps, J. E., and DiCarlo, F. J. (1973). Prazepam metabolism in the rat. J. Pharm. Sci. 62, 641-645.

WhITE, B. J., DRISCOLL, E. J., TuO, J. H., AND SMILACK, Z. H. (1974). Chromosomal aberration rates and intravenously given diazepam. J. Amer. Med. Assoc. 230, 414-417.

ZBinden, G., Randall, L. O., Bagdon, R. E., KeITH, E. F., AND PHILlIPS, R. D. (1961). Experimental and clinical toxicology of chlordiazepoxide (Librium). Toxicol. Appl. Pharmacol. 3, 619-637. 